\title{
Whole genome sequencing in the study of disease and application in personalised medicine
}

\author{
A Kumarasuriyar \\ From Familial Aspects of Cancer 2011 Research and Practice: A combined meeting of kConFab, Australian \\ Breast Cancer Family Study, Australian Colorectal Cancer Family Study, Australian Ovarian Cancer Study, \\ Family Cancer Clinics of Australia and New Zealand and kConFab \\ Kingscliff, Australia. 23-26 August 2011
}

Next Generation Sequencing has enabled a range of applications to investigate nearly every facet of genomic science including variant detection, transcriptome profiling and epigenetic studies. Many of these applications were previously either impractical or uneconomical by Sanger sequencing. In particular, whole genome and exome sequencing are now within the reach of an increasing number of researchers due to continued reduction in costs, improvements in workflow and accessibility of appropriate technologies. Furthermore, the improvements in data handling, storage and analysis tools have contributed significantly in providing biologist-friendly methods to assemble reads and call variants.

Here I will review the recent application of whole genome and exome sequencing in both clinical and research environments for the study of breast cancer. Specifically, a recent whole-genome investigation of 50 tumour-normal pairs sourced from oestrogen receptor positive breast cancers will be explored. This study confirmed genes previously implicated in this type of cancer, as well as identifying 3 new candidates; MAP3K1, ATR and MYST. To improve clinical outcomes, it is hoped that whole genome sequencing in this study will identify treatment-resistance mechanisms for cancers sourced from women resistive to oestrogen-lowering treatment.

Additional case studies will be used to highlight how these techniques have advanced our understanding in determining the treatment and subsequent clinical outcomes for individuals suffering from rare diseases.

Published: 12 April 2012

Illumina, San Diego, CA, USA
doi:10.1186/1897-4287-10-S2-A39

Cite this article as: Kumarasuriyar: Whole genome sequencing in the study of disease and application in personalised medicine. Hereditary Cancer in Clinical Practice 2012 10(Suppl 2):A39.
Submit your next manuscript to BioMed Central and take full advantage of:

- Convenient online submission

- Thorough peer review

- No space constraints or color figure charges

- Immediate publication on acceptance

- Inclusion in PubMed, CAS, Scopus and Google Scholar

- Research which is freely available for redistribution
() Biomed Central

\section{Biomed Central}

(c) 2012 Kumarasuriyar; licensee BioMed Central Ltd. This is an Open Access article distributed under the terms of the Creative Commons Attribution License (http://creativecommons.org/licenses/by/2.0), which permits unrestricted use, distribution, and reproduction in any medium, provided the original work is properly cited. 